\title{
Slurry-phase Ethylene Polymerization using Pentafluorophenyl- and Pentafluorophenoxy-Modified Solid Polymethylaluminoxanes
}

\author{
Alexander F. R. Kilpatrick, ${ }^{\dagger}$ Nicholas H. Rees, ${ }^{\dagger}$ Saovalak Sripothongnak, ${ }^{\ddagger}$ Jean-Charles Buffet $^{\dagger}$ \\ and Dermot O'Hare ${ }^{\dagger *}$ \\ ${ }^{\dagger}$ Chemistry Research Laboratory, Department of Chemistry, University of Oxford, 12 Mansfield Road, Oxford, OX1 \\ 3TA, U.K. \\ ${ }^{\ddagger}$ SCG Chemicals Co., Ltd, 1 Siam Cement Rd, Bangkok 108oo, Thailand.
}

Supporting Information Placeholder

ABSTRACT: Post synthesis modification of solid polymethylaluminoxane (sMAO) with tris(pentafluorophenyl)borane or
pentafluorophenol produces highly active metallocene supports "sMMAOs" for use in slurry-phase ethylene polymeriza-
tion. Characterization of the sMMAOs using ICP-MS analysis, BET isotherm, SEM-EDX, diffuse FT-IR and solid state
NMR spectroscopy reveals that the surface methyl groups are exchanged for $\mathrm{C}_{6} \mathrm{~F}_{5}$ and $\mathrm{C}_{6} \mathrm{~F}_{5} \mathrm{O}$ moieties respectively, giving a
material with reduced aluminum content and a lower specific surface area than sMAO. Rac-ethylenebis(1-indenyl) zirco-
nium dichloride, $\left\{(\mathrm{EBI}) \mathrm{ZrCl}_{2}\right\}$ immobilized on $\mathrm{B}\left(\mathrm{C}_{6} \mathrm{~F}_{5}\right)_{3}$ and $\mathrm{C}_{6} \mathrm{~F}_{5} \mathrm{OH}$ modified sMAO displayed activity increases of 66 and
$71 \%$ respectively for ethylene polymerization compared to the same zirconocene catalyst precursor on unmodified sMAO.
In the case of $\mathrm{B}\left(\mathrm{C}_{6} \mathrm{~F}_{5}\right)_{3}$ modified sMAO this enhanced polymerization activity is accompanied by excellent control of pol-
ymer particle size and morphology, and a small decrease in polymer molecular weight and polydispersities.

\section{INTRODUCTION}

Methylaluminoxane (MAO) is widely used as a potent activator for metallocene complexes in olefin polymerization. ${ }^{1}$ The precise structure of this oligomeric material has been the subject of longstanding debate, due to its complicated and dynamic composition. ${ }^{2-4}$ There has been significant progress in the last few years in the characterization of MAO and its function as a source of an electrophilic cation, $\left[\mathrm{AlMe}_{2}\right]^{+}$, which plays a key role in the activation of metallocene complexes..$^{5-10}$ Computational models of MAO indicate that with increasing aggregation of $[\mathrm{Al}(\mathrm{O}) \mathrm{Me}]$ units, the structure changes from sheets to nanotubes to cages. ${ }^{11,12}$ Strategies to modify MAO have mainly focussed on improving its solubility and stability in solution. For example, replacement of methyl groups for larger alkyls such as Et, ${ }^{i} \mathrm{Bu}$ or Oct results in a modified aluminoxane species, so-called MMAO, that exhibits higher solubility but lower activity. ${ }^{13,14}$ Other strategies have involved addition of dopants to soluble MAO. Addition of electron donors such as 2,2,6,6tetramethylpiperidine (TMP) were shown to decrease polymerization activity, whereas addition of electron acceptors such as $(\mathrm{MeBO})_{3}, \mathrm{R}_{2} \mathrm{~B}(\mathrm{OH})$ and $\mathrm{RB}(\mathrm{OH})_{2}$ were found to enhance the activity. ${ }^{13,15}$

Park and co-workers reported that MAO solutions can be modified by the addition of Lewis acids such as $\mathrm{B}\left(\mathrm{C}_{6} \mathrm{~F}_{5}\right)_{3}$ or $\mathrm{Al}\left(\mathrm{C}_{6} \mathrm{~F}_{5}\right)_{3}$ (Scheme 1a). ${ }^{16}$ These researchers sug- gested that an alkyl exchange reaction occurs between the methyl groups of the MAO backbone and the $\mathrm{C}_{6} \mathrm{~F}_{5}$ groups of the modifiers. These modified MAOs (MMAOs) were tested as activators and co-catalysts for solution phase olefin polymerization; when $\mathrm{Al}\left(\mathrm{C}_{6} \mathrm{~F}_{5}\right)_{3}$ was used in a $0.0055 \mathrm{~mol}_{\mathrm{M}}$ loading with respect to MAO, a 7 -fold increase in activity for polyethylene was observed.

Scheme 1. Schematic of the synthetic routes to (a) Lewis acid; (b) phenoxy modified MAO solutions; and (c) free TMA removal. A linear MAO formula is shown for simplicity.

(a)
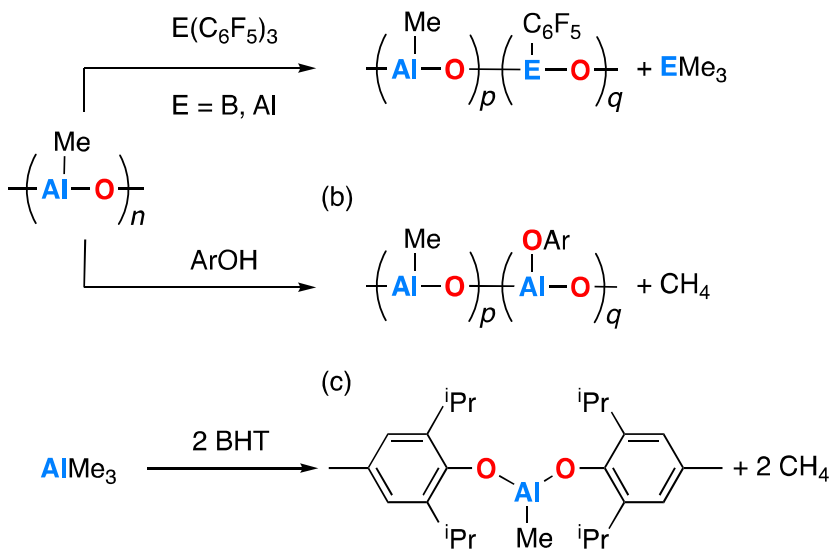
Aryloxide modified MAO solutions have also been synthesized, ${ }^{17-21}$ either via protonolysis of MAO with a phenolic reagent (Scheme $1 \mathrm{~b}$ ), or by reaction of trimethylaluminum (TMA) with a phenol followed by controlled hydrolysis of the product with water. In ethylene polymerization studies, Kissin found that bulky 2,6disubstituted phenols and pentafluorophenol have a positive effect on the activating capabilities of the obtained MMAO. ${ }^{19,20}$ Another well-known chemical treatment of MAO utilizes hindered phenols such as 2,6-di-tert-butyl4-methylphenol (BHT) to scavenge the 'free' trimethylaluminum (TMA) present in MAO solutions, yielding a hindered phenoxide-alkylaluminum species (Scheme 1c) that does not interact with the catalyst complex. The remaining TMA depleted MAO (dMAO) is also an effective catalyst activator which can increase the activity and molecular weight of the resulting polymer, ${ }^{22-24}$ depending on the nature of the pre-catalyst complex. ${ }^{25}$

The heterogenization of molecular single-site catalyst precursors is required for gas phase or slurry phase olefin polymerization. ${ }^{26-29}$ A large number of inorganic-based catalyst supports have been developed for these purposes; commonly using MAO impregnated on inert 'carrier' materials such as clays, silicas, zirconium oxide, magnesium halides, alumina and zeolites, with silica being the most important for slurry-phase olefin polymerization. ${ }^{30-33} \mathrm{Hy}-$ brid metal-organic supports containing fluorine are also of growing interest, as they can immobilize metallocene complexes to produce highly active catalyst systems without the need for MAO or borate salts. ${ }^{34-36}$ One strategy to improving the overall performance of catalyst systems is by tuning the support to provide higher activity or generate different polymer properties, whilst maintaining the single-site nature of the immobilized complex. ${ }^{37,38}$ There is also a significant interest in increasing the particle size of single-site supported catalysts, ${ }^{27}$ which has benefits for the industrial application of this technology as it can prevent reactor fouling. ${ }^{29}$

Electron withdrawing compounds such as pentafluorophenol have been reported in the patent literature as modifiers for silica-supported MAO. ${ }^{39}$ Sauter et al. have recently extended this approach using the concept of surface organometallic chemistry, and synthesized a welldefined bipodal bis(pentafluorophenol) aluminate $\left[(\equiv \mathrm{SiO})_{2} \mathrm{Al}\left(\mathrm{OC}_{6} \mathrm{~F}_{5}\right)_{2}\right]^{-}\left[\mathrm{HNEt}_{2} \mathrm{Ph}\right]^{+}$(Scheme 2). ${ }^{40}$ This solid was characterized by solid state NMR and DRIFT spectroscopy and proved to be an activating support for zirconocene pre-catalysts (EBI) $\mathrm{ZrCl}_{2}$ and ${ }^{n{ }^{n B}} \mathrm{Cp}_{2} \mathrm{ZrCl}_{2}$ in slurry-phase ethylene polymerization reactions, with and without 1-hexene as the co-monomer. The catalytic activity and the physical properties of the resultant polymers were comparable with the classical industrial standard, namely silica-supported MAO using the same zirconocene complexes. ${ }^{29,41}$

Scheme 2. Schematic of the preparation of a bis(pentafluorophenoxy)aluminate activating support. $^{40}$

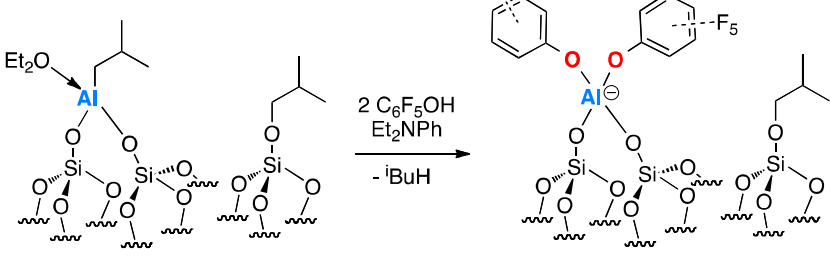

In 2005, researchers at Borealis reported an alternative emulsion-based heterogenization technique for single-site polymerization catalysts. ${ }^{42}$ In this method, a pre-activated metallocene-MAO solution in toluene was used to form an emulsion by addition to a cooled perfluorooctane containing a surfactant-MAO - prepared in situ by reaction of perfluoroheptanol and MAO. This cooled emulsion was solidified by addition to hot perfluorooctane, to produce uniformly spherical catalyst particles that were active for the copolymerisation of ethylene and 1-hexene. Such 'selfsupported' catalysts have the advantage over silicasupported systems as the complex loading can be increased significantly, which leads to correspondingly higher polymerization activities.

Another carrier-free support material, solid polymethylaluminoxane (sMAO), is a hydrocarbon insoluble form of methylaluminoxane that was originally reported in the patent literature by Tosoh Finechemicals, Japan. ${ }^{31}$ We have recently reported the laboratory scale synthesis and detailed characterization of $\mathrm{sMAO},{ }^{43}$ and demonstrated its function as a support, scavenger and activator in slurry-phase ethylene polymerization. Observed activities are significantly higher than for other supports; for example sMAO-rac-ethylenebis(1-permethylindenyl) zirconium dichloride is at least three times more active than its silica-supported MAO counterpart (5365 vs. $1649 \mathrm{~kg}_{\mathrm{PE}} \mathrm{mol}_{\mathrm{Zr}}{ }^{-}$ ${ }^{1} \mathrm{~h}^{-1}$ bar $^{-1}$ respectively). ${ }^{44,45}$

Characterization of sMAO using multinuclear NMR spectroscopy in solution and the solid state reveals an aluminoxane structure that features 'free' and bound Al$\mathrm{Me}_{x}$ units and a benzoate residue. Total X-ray scattering measurements on sMAO allow comparisons to be made with simulated data for DFT modelled structures of MAO. We found that TMA-capped nanotubes (AlO$\mathrm{Me})_{9, \mathrm{t}} \cdot\left(\mathrm{AlMe}_{3}\right)_{3}$ or cage structures $(\mathrm{AlOMe})_{20, \mathrm{c}} \cdot\left(\mathrm{AlMe}_{3}\right)_{m}, n$ $>20, m=1,2$, best account for the experimental data. ${ }^{46,47}$

Herein, we report the synthesis, characterization and catalytic performance of pentafluorophenyl and pentafluorophenoxy-modified solid polymethylaluminoxanes (sMMAO), which act as efficient activating supports for slurry-phase ethylene polymerization. The aim of these studies is to design and synthesize a commercially effective solid support for a zirconocene-based polymerization system with a decreased aluminum content that can deliver commercially relevant catalytic activities and produce industrial-grade polyethylene.

\section{RESULTS AND DISCUSSION}


Synthetic modification of solid polyaluminoxanes (sMMAOs)

Solid polymethylaluminoxane (sMAO) may be synthesized by the controlled hydrolysis of TMA with benzoic acid, ${ }^{48}$ followed by two thermolysis steps (Scheme 3 ). We have reported that the ratio of these reactants is critical to the function of sMAO as an activating support, ${ }^{43}$ with an $[\mathrm{Al}]:[\mathrm{O}]$ ratio of 1.2 giving highest ethylene polymerization activity. Our starting point for the current study focussed on introducing $\mathrm{C}_{6} \mathrm{~F}_{5} \mathrm{OH}$ as a modifier compound at different stages in this procedure.

Scheme 3. Optimized procedure for the synthesis of SMAO. ${ }^{43}$

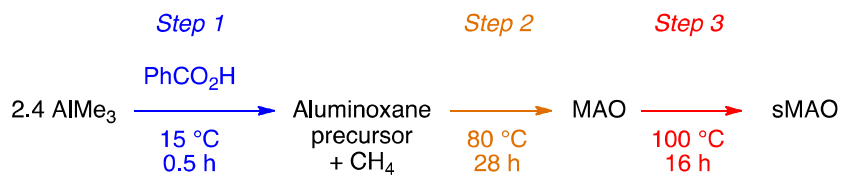

Reactions of $\mathrm{C}_{6} \mathrm{~F}_{5} \mathrm{OH}$ with the TMA-benzoic acid mixture after Step 1, Step 2 and Step 3 of the procedure all yielded colorless solids, so-called synthesized sMMAO $\left(\mathrm{C}_{6} \mathrm{~F}_{5} \mathrm{OH}\right)$, which were characterized by NMR spectroscopy, $\mathrm{N}_{2}$ physisorption and ICP-MS analysis. However, screening the synthesized sMMAO $\left(\mathrm{C}_{6} \mathrm{~F}_{5} \mathrm{OH}\right)$ samples as supports for (EBI) $\mathrm{ZrCl}_{2}$ in slurry-phase ethylene polymerization reactions, revealed in each case a lower activity with respect to the synthesized sMAO control, and SEM imaging of the polyethylene samples revealed a poor irregular morphology. McKenna and coworkers have made significant progress in describing the complex relationship between catalyst particle morphology, rate of reaction and polymer properties. ${ }^{49^{-52}}$ Highly amorphous polymer particles were modelled by an increased rate of stress generation in the pore space of the material, leading to early fragmentation at low polymer yields. ${ }^{50}$ The polyethylene samples obtained from synthesized sMMAO $\left(\mathrm{C}_{6} \mathrm{~F}_{5} \mathrm{OH}\right)-(\mathrm{EBI}) \mathrm{ZrCl}_{2}$ catalysts appear to fit this model.

Full synthetic procedures, characterization data and polymerization studies for the synthesized sMMAO $\left(\mathrm{C}_{6} \mathrm{~F}_{5} \mathrm{OH}\right)$ samples are included in the Supporting Information. Of these supports, the $\operatorname{sMMAO}\left(\mathrm{C}_{6} \mathrm{~F}_{5} \mathrm{OH}\right)$ produced via a post-synthesis modification of sMAO showed the most promising catalytic performance, and therefore this synthetic route was investigated further.

The post-synthesis modification of sMAO was carried out on a preparative scale using two modifiers (M), $\mathrm{B}\left(\mathrm{C}_{6} \mathrm{~F}_{5}\right)_{3}$ and $\mathrm{C}_{6} \mathrm{~F}_{5} \mathrm{OH}$, using a range of $\mathrm{M}: \mathrm{Al}$ mole ratios in reactants (0.01, 0.05, 0.10 and 0.20 ) in order to study the effect of modifier loading on sMMAO structure and performance as an activating support. For brevity, each modified solid polymethylaluminoxane prepared herein will be represented as $\operatorname{sMMAO}(x / \mathrm{M})$, where $x$ is the $[\mathrm{M}] /[\mathrm{Al}]$ loading in reactants, and $\mathrm{M}$ is the reactant modifier compound.

In a typical experiment, sMAO was suspended in toluene, a solution of the modifier in toluene was added, and the reaction mixture was placed in an ultrasound bath. Sonication for $1 \mathrm{~h}$ led to an increase in water bath temperature from 25 to $45{ }^{\circ} \mathrm{C}$, longer periods were avoided to prevent possible thermal decomposition, as reported for $\operatorname{MMAO}\left(\mathrm{B}\left(\mathrm{C}_{6} \mathrm{~F}_{5}\right)_{3}\right){ }^{16}$ Following cooling to room temperature, the resultant slurry was then treated with hexane to extract the by-products and encourage precipitation of a colorless solid. After settling, the supernatant solution was removed, and the solids were washed, vacuum dried and isolated in good to quantitative yield (73-99\% with respect to aluminum). A control reaction was also carried out, using an identical procedure but without the addition of a modifying compound.

\section{Characterization of sMMAO samples}

Initial test reactions of sMAO with $\mathrm{B}\left(\mathrm{C}_{6} \mathrm{~F}_{5}\right)_{3}$ and $\mathrm{C}_{6} \mathrm{~F}_{5} \mathrm{OH}$ were carried out on a small scale in a J. Young NMR tube using a $[\mathrm{M}] /[\mathrm{Al}]$ loading of 0.10 , and monitored by ${ }^{1} \mathrm{H}$ and ${ }^{19}$ F NMR spectroscopy. Solid MAO is insoluble in aromatic and aliphatic hydrocarbons (no ${ }^{1} \mathrm{H}$ NMR spectrum was observed in cyclohexane- $d_{12}$ and toluene- $d_{8}$ ) but is sufficiently soluble in THF- $d_{8}$, to be studied by solution NMR spectroscopy. Samples of sMAO and $\mathrm{B}\left(\mathrm{C}_{6} \mathrm{~F}_{5}\right)_{3}$ were mixed at room temperature with THF- $d_{8}$, however only NMR resonances attributed to $\left(\mathrm{C}_{6} \mathrm{~F}_{5}\right)_{3} \mathrm{~B}(\mathrm{THF})$ and sMAO were identified, and heating the mixture to $80{ }^{\circ} \mathrm{C}$ resulted in the formation of a gelatinous solid which precluded further characterization. Klosin et al. reported a similar finding that aryl/alkyl group exchange reactions between $\left(\mathrm{C}_{6} \mathrm{~F}_{5}\right)_{3} \mathrm{~B}(\mathrm{THF})$ and TMA do not occur in coordinating solvents. ${ }^{53} \mathrm{~A}$ mixture of sMAO and $\mathrm{B}\left(\mathrm{C}_{6} \mathrm{~F}_{5}\right)_{3}([\mathrm{M}] /[\mathrm{Al}]=$ o.10) in toluene- $d_{8}$ was shaken at room temperature, settling into a white solid beneath a colorless solution. NMR spectroscopy revealed the formation of $\left(\mathrm{C}_{6} \mathrm{~F}_{5}\right)_{2} \mathrm{BMe}^{54-56}$ in $44 \%$ conversion after sonication for $1 \mathrm{~h}$ at a temperature of $25-45^{\circ} \mathrm{C}$ (Figure $\mathrm{S} 1$ in the Supporting Information). The formation of $\left(\mathrm{C}_{6} \mathrm{~F}_{5}\right)_{2} \mathrm{BMe}$ is consistent with exchange of a $\mathrm{C}_{6} \mathrm{~F}_{5}$ ligand for a $\mathrm{CH}_{3}$ group in sMAO, as observed in the room temperature reaction of TMA and $\mathrm{B}\left(\mathrm{C}_{6} \mathrm{~F}_{5}\right)_{3}$ in toluene- $d_{8}$, which affords $\left(\mathrm{C}_{6} \mathrm{~F}_{5}\right)_{x} \mathrm{Al}_{2} \mathrm{Me}_{6-x}(x=0-6)$ and $\mathrm{BMe}_{3}$ in a mixture that is dependent on the $\mathrm{Al}: \mathrm{B}$ ratio employed. ${ }^{56}$

Addition of a toluene- $d_{8}$ solution of $\mathrm{C}_{6} \mathrm{~F}_{5} \mathrm{OH}$ to sMAO $([\mathrm{M}] /[\mathrm{Al}]=0.1)$, resulted in rapid effervescence of gas, identified as methane in the ${ }^{1} \mathrm{H}$ NMR spectrum (singlet at $\left.\delta_{\mathrm{H}} 0.17 \mathrm{ppm}\right)$. After 15 minutes sonication at room temperature the ${ }^{19} \mathrm{~F}$ NMR signals of $\mathrm{C}_{6} \mathrm{~F}_{5} \mathrm{OH}$ had diminished entirely, suggesting quantitative transfer of the $\mathrm{C}_{6} \mathrm{~F}_{5} \mathrm{O}$ group onto the precipitated solid.

For both of these test reactions, the toluene- $d_{8}$ supernatant solution was removed by filtration and the insoluble material was dried under vacuum. In each case, the colorless solid residues were sparingly soluble in THF- $d_{8}$ and NMR spectra $\left({ }^{1} \mathrm{H},{ }^{19} \mathrm{~F},{ }^{27} \mathrm{Al}\right)$ were measured (Figures $\mathrm{S}_{2}-\mathrm{S}_{7}$ in the Supporting Information). The methyl region of the ${ }^{1} \mathrm{H}$ NMR spectra proved the most diagnostic for monitoring these reactions, exhibiting a sharp resonance at $\delta_{\mathrm{H}}-0.64 \mathrm{ppm}$ for sMMAO $\left(0.10 / \mathrm{B}\left(\mathrm{C}_{6} \mathrm{~F}_{5}\right)_{3}\right)$ and $\delta_{\mathrm{H}}-0.82$ ppm for $\operatorname{sMMAO}\left(0.10 / \mathrm{C}_{6} \mathrm{~F}_{5} \mathrm{OH}\right)$, assigned to the $\mathrm{AlMe}$ 
protons adjacent to a $\mathrm{C}_{6} \mathrm{~F}_{5}$ and $\mathrm{C}_{6} \mathrm{~F}_{5} \mathrm{O}$ group respectively. The ${ }^{1} \mathrm{H}$ NMR spectra also show features common to unmodified sMAO, including a broad methyl resonance $\left(\delta_{\mathrm{H}}\right.$ -0.20 to $-1.20 \mathrm{ppm})$ and two sharp resonances $\left(\delta_{\mathrm{H}}-0.60\right.$ and $-0.96 \mathrm{ppm})$, assigned to bound and free $\mathrm{AlMe}$ units respectively, which remain in the structure. ${ }^{2,6}$ Relative integration of the latter resonance in the $\operatorname{sMMAO}(x / \mathrm{M})$ ${ }^{1} \mathrm{H}$ NMR spectra (Tables $\mathrm{S}_{2}-\mathrm{S}_{3}$ in the Supporting Information) reveals a general decrease in free $\mathrm{AlMe}_{x}$ with increasing modifier loading. We tentatively propose that the free $\mathrm{AlMe}_{x}$ component of sMAO reacts preferentially with the modifier compounds according to Scheme 4 , and becomes bound to the core aluminoxane structure. A similar mode of reactivity for solution MAO has been reported by Macchioni and co-workers, ${ }^{57}$ in which TMAdepleted MAO (dMAO) was shown to react with 2,6-ditert-butylphenol to produce -OAl(OAr) "decorated" dMAO.

Scheme 4. Schematic of the synthesis of $B\left(C_{6} F_{5}\right)_{3}$ and $\mathrm{C}_{6} \mathrm{~F}_{5} \mathrm{OH}$ modified sMAO and schematic representations of their proposed structures.

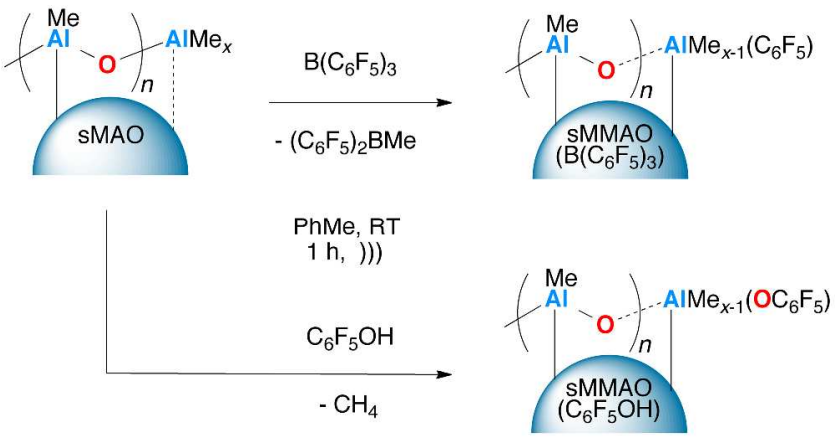

Solid samples were analysed by solid state NMR (SSNMR) spectroscopy in order to provide more insight into the structure of the sMMAO materials. The ${ }^{19} \mathrm{~F}\left\{{ }^{1} \mathrm{H}\right\}$ DP-MAS SSNMR spectrum of $\operatorname{sMMAO}\left(0.10 / \mathrm{B}\left(\mathrm{C}_{6} \mathrm{~F}_{5}\right)_{3}\right)$ (Figure 1a) shows resonances centered at $-125.3,-159.3$ (shoulder) and $-165.8 \mathrm{ppm}$, assigned to a bound $\mathrm{C}_{6} \mathrm{~F}_{5}$ group on the basis of similar isotropic $\delta_{\mathrm{F}}$ values in $\mathrm{Al}\left(\mathrm{C}_{6} \mathrm{~F}_{5}\right)_{3}$ (Figure S9 in the Supporting Information) and silica-supported borane species $(\equiv \mathrm{SiO})_{n} \mathrm{~B}\left(\mathrm{C}_{6} \mathrm{~F}_{5}\right)_{3-n \cdot{ }^{5}}$ For comparison, the ${ }^{19} \mathrm{~F}\left\{{ }^{1} \mathrm{H}\right\}$ solution NMR spectra of $\mathrm{B}\left(\mathrm{C}_{6} \mathrm{~F}_{5}\right)_{3}$ modified sMAO in THF- $d_{8}$ solution (after washing of the sample with toluene-hexane) showed a principal set of three resonances at $-123.2,-158.3$ and $-164.2 \mathrm{ppm}$ assigned to the $o^{-}, p^{-}$and $m$-positions of the bound $\mathrm{C}_{6} \mathrm{~F}_{5}$ group respectively. Samples of sMAO modified with $\mathrm{Al}\left(\mathrm{C}_{6} \mathrm{~F}_{5}\right)_{3}$ and $\left(\mathrm{C}_{6} \mathrm{~F}_{5}\right)_{2} \mathrm{AlCl}$ each showed identical ${ }^{19} \mathrm{~F}$ NMR resonances as sMMAO $\left(0.10 / B\left(C_{6} F_{5}\right)_{3}\right)$ in THF- $d_{8}$ solution, supporting the proposed $\mathrm{Me} / \mathrm{C}_{6} \mathrm{~F}_{5}$ ligand exchange. The ${ }^{1} \mathrm{H}{ }^{13} \mathrm{C}\left\{{ }^{19} \mathrm{~F}\right\}$ CP-MAS SSNMR spectrum of $\operatorname{sMMAO}\left(0.10 / \mathrm{B}\left(\mathrm{C}_{6} \mathrm{~F}_{5}\right)_{3}\right)$ (Figure $1 \mathrm{~b}$ ) shows an intense signal at $-7.9 \mathrm{ppm}$, assigned to the various $\mathrm{CH}_{3}$ environments in the aluminoxane backbone, and several overlapping resonances in the aromatic region (150-127 ppm), which are assigned to the phenyl ${ }^{13} \mathrm{C}$ nuclei of the benzoate and pentafluorophenyl residues. The ${ }^{19} \mathrm{~F}{ }^{13} \mathrm{C}\left\{{ }^{1} \mathrm{H}\right\}$ CP-MAS SSNMR spectrum (Figure $1 \mathrm{~b}$, inset) shows 3 principal resonances at 140.7, 128.5 and $102.0 \mathrm{ppm}$, in the expected region for an aluminumbound $\mathrm{C}_{6} \mathrm{~F}_{5}$ group (Figure $\mathrm{S} 10$ in the Supporting Information). No ${ }^{11} \mathrm{~B}$ resonances were observed in the solution or solid state NMR spectra of $\mathrm{B}\left(\mathrm{C}_{6} \mathrm{~F}_{5}\right)_{3}$ modified samples, and elemental analysis confirmed that no boron was incorporated into the aluminoxane structure.

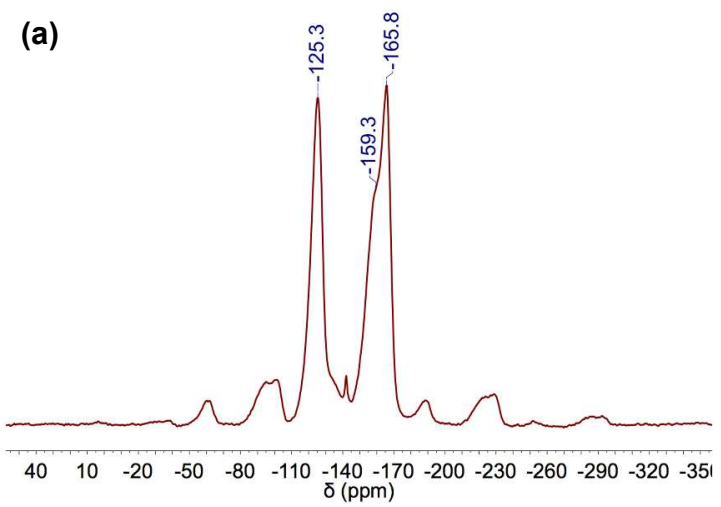

(b)
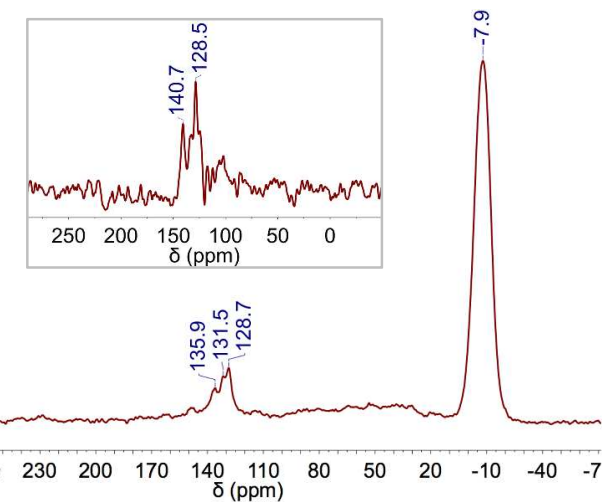

Figure 1. Solid state NMR spectra of $\left.\operatorname{sMMAO}\left(0.10 / \mathrm{B}_{(} \mathrm{C}_{6} \mathrm{~F}_{5}\right)_{3}\right)$; (a) ${ }^{19} \mathrm{~F}\left\{{ }^{1} \mathrm{H}\right\}$ DP-MAS; (b) ${ }^{1} \mathrm{H}-{ }^{13} \mathrm{C}-\left\{{ }^{19} \mathrm{~F}\right\}$ and (inset) ${ }^{19} \mathrm{~F}{ }^{-13} \mathrm{C}\left\{{ }^{1} \mathrm{H}\right\}$ CP-MAS SSNMR. Additional SSNMR spectra are shown in the Supporting Information.

The ${ }^{19} \mathrm{~F}\left\{{ }^{1} \mathrm{H}\right\} \quad$ DP-MAS SSNMR spectra of sMMAO(o.10/ $\mathrm{C}_{6} \mathrm{~F}_{5} \mathrm{OH}$ ) (Figures $\mathrm{S}_{13}-\mathrm{S}_{14}$ in the Supporting Information) show resonances centered at $-166 \mathrm{ppm}$, with spinning sidebands, consistent with the incorporation of a pentafluorophenoxy group. For comparison, the ${ }^{19} \mathrm{~F}\left\{{ }^{1} \mathrm{H}\right\}$ solution NMR spectra sMMAO(o.10/ $\left.\mathrm{C}_{6} \mathrm{~F}_{5} \mathrm{OH}\right)$ in THF- $d_{8}$ solution showed three resonances at $-164.8,-169.0$ and $177.4 \mathrm{ppm}$ assigned to the $o^{-}, p^{-}$and $m$-positions of the bound $\mathrm{C}_{6} \mathrm{~F}_{5}$ group respectively. These separate chemical environments are not resolved in the ${ }^{19} \mathrm{~F}$ SSNMR spectra due to broader linewidths of the resonances. The ${ }^{1} \mathrm{H}{ }^{13} \mathrm{C}$ $\left\{{ }^{19} \mathrm{~F}\right\}$ CP-MAS SSNMR spectrum of $\operatorname{sMMAO}\left(0.10 / \mathrm{C}_{6} \mathrm{~F}_{5} \mathrm{OH}\right)$ (Figure $\mathrm{S}_{15}$ in the Supporting Information) shows similar features to that of sMAO, apart from a resonance at 138.7 ppm, assigned to the phenyl ${ }^{13} \mathrm{C}$ nuclei of the $\mathrm{C}_{6} \mathrm{~F}_{5} \mathrm{O}$ modifier group. The ${ }^{19} \mathrm{~F} \stackrel{13}{\rightarrow} \mathrm{C}\left\{{ }^{1} \mathrm{H}\right\}$ CP-MAS SSNMR spectrum of $\mathrm{C}_{6} \mathrm{~F}_{5} \mathrm{OH}$ modified sMAO shows a single resonance at 138.5 ppm (Figure $\mathrm{S} 16$ in the Supporting Information), consistent with the assignment proposed.

The ${ }^{27} \mathrm{Al}$ Hahnecho ${ }^{59}$ SSNMR spectra of sMMAO $\left(0.10 / \mathrm{B}\left(\mathrm{C}_{6} \mathrm{~F}_{5}\right)_{3}\right)$ and $\left(0.10 / \mathrm{C}_{6} \mathrm{~F}_{5} \mathrm{OH}\right)$ at $15 \mathrm{kHz}$ both show a broad envelope between $630--715$ ppm, which is very 
similar to that of the unmodified sMAO (Figures S12 and $\mathrm{S} 17$ in the Supporting Information). ${ }^{43}$

Diffuse reflectance Fourier transform infrared (DRIFT) spectroscopy was employed to further characterize the structural properties of the active supports (Figures S18S2o in the Supporting Information). The DRIFT spectrum of sMAO shows several bands between $2700-3100 \mathrm{~cm}^{-1}$ and ca. $1445 \mathrm{~cm}^{-1}$ characteristic of $v(\mathrm{C}-\mathrm{H})$ and $\delta(\mathrm{C}-\mathrm{H})$ modes respectively. ${ }^{60}$ Infrared bands at ca. 1257 and 1220 $\mathrm{cm}^{-1}$ are assigned to bridging and terminal- $\mathrm{CH}_{3}$ groups respectively by comparison with FT-IR spectra of MAO. ${ }^{61,62}$

The DRIFT spectra of sMMAO $\left(0.10 / \mathrm{B}\left(\mathrm{C}_{6} \mathrm{~F}_{5}\right)_{3}\right)$ and $\left(0.10 / \mathrm{C}_{6} \mathrm{~F}_{5} \mathrm{OH}\right)$ displayed new bands at 1641 and $1654 \mathrm{~cm}^{-1}$ respectively (Figure 2 ), that are assigned to the aromatic ring stretching modes $v\left(\mathrm{C}_{\mathrm{sp} 2}=\mathrm{C}_{\mathrm{sp} 2}\right)$ of the $\mathrm{C}_{6} \mathrm{~F}_{5}$ and $\mathrm{C}_{6} \mathrm{~F}_{5} \mathrm{O}$ groups. ${ }^{63-66}$ These bands increase in relative intensity as the molar loading of modifier is increased (Figures S21S22 in the Supporting Information).

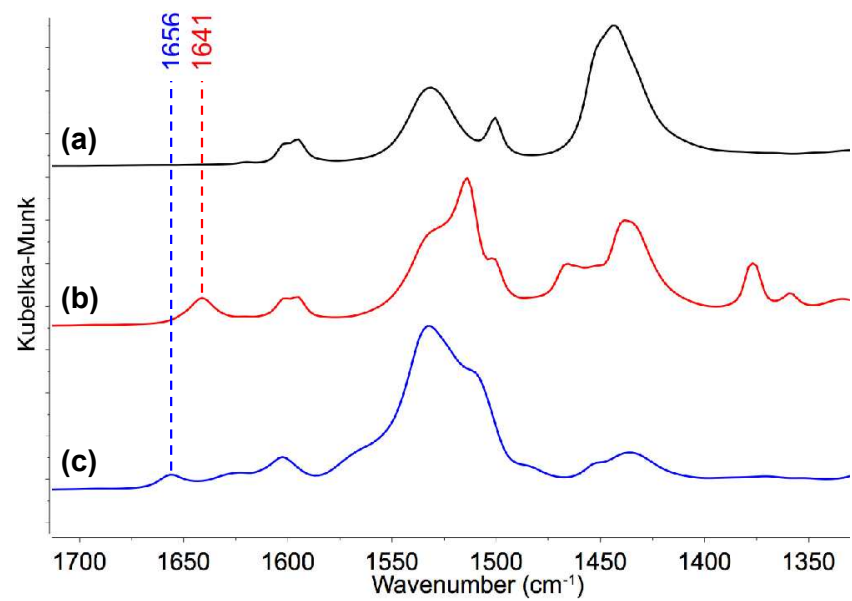

Figure 2. Selected region of the DRIFT spectra $(\mathrm{NaCl}$ window) of (a) sMAO (b) $\operatorname{sMMAO}\left(0.10 / \mathrm{B}\left(\mathrm{C}_{6} \mathrm{~F}_{5}\right)_{3}\right)$ and (c) sMMAO $\left(0.10 / \mathrm{C}_{6} \mathrm{~F}_{5} \mathrm{OH}\right)$. Spectra are vertically offset for clarity with aromatic ring stretching modes of the $\mathrm{C}_{6} \mathrm{~F}_{5}$ groups highlighted. Additional DRIFT spectra are shown in the Supporting Information.

Pyridine is often used as a probe molecule for the characterization of Lewis acidity in metal oxides, ${ }^{67}$ with an increase in the IR stretching frequency of the $v_{8 a}$ mode for coordinated $\mathrm{C}_{5} \mathrm{H}_{5} \mathrm{~N}$ (which is $1596 \mathrm{~cm}^{-1}$ for the free molecule) being correlated with higher Lewis acidity. The DRIFT spectrum of sMAO after exposure to $\mathrm{C}_{5} \mathrm{H}_{5} \mathrm{~N}_{(\mathrm{g})}$ contains a new band at $1619 \mathrm{~cm}^{-1}$ (Figure $\mathrm{S}_{23}$ in the Supporting Information), consistent with the $v_{8 \mathrm{a}}$ mode of pyridine bound to a highly Lewis acidic $\mathrm{Al}$ site. ${ }^{68,69}$ For comparison, FT-IR spectra of $\gamma-\mathrm{Al}_{2} \mathrm{O}_{3}$ and $\mathrm{SiO}_{2}-\mathrm{Al}_{2} \mathrm{O}_{3}$ show the $v_{8 \mathrm{a}}$ mode of pyridine bound at 1625 and $1622 \mathrm{~cm}^{-1}$ respectively. ${ }^{69,70}$ When sMMAO samples were exposed to $\mathrm{C}_{5} \mathrm{H}_{5} \mathrm{~N}_{(\mathrm{g})}$ an IR band at $1619 \mathrm{~cm}^{-1}$ was also present (Figures $\mathrm{S}_{24}-\mathrm{S} 25$ in the Supporting Information), and the positions of the respective $\mathrm{C}_{6} \mathrm{~F}_{5}$ ring-breathing modes were essentially unaffected by the presence of pyridine. These observations are consistent with pyridine binding to a Lewis acidic $\mathrm{Al}$ site that is the same for modified and unmodified
sMAO samples, and that the surface-bound $\mathrm{C}_{6} \mathrm{~F}_{5}$ and $\mathrm{C}_{6} \mathrm{~F}_{5} \mathrm{O}$ groups in the modified samples do not directly effect the Lewis acid/base binding interaction with this probe molecule.

The aluminum content in the sMMAO samples was determined by ICP-MS analysis, which shows a progressive decrease in $\mathrm{Al}$ with increasing $\mathrm{M}$ loading from 38.5 wt $\%$ for the control sMAO to ca. $25 \mathrm{wt} \%$ in the sMMAO(o.20/M). This is consistent with the replacement of Al-bound methyl groups with heavier modifier groups. The amount of fluorine, as quantified by elemental analysis is $6.94 \mathrm{wt} \%$ for $\operatorname{MMAO}\left(0.10 / \mathrm{B}\left(\mathrm{C}_{6} \mathrm{~F}_{5}\right)_{3}\right)$ and $11.2 \mathrm{wt} \%$ for sMMAO(o.10/ $\left.\mathrm{C}_{6} \mathrm{~F}_{5} \mathrm{OH}\right)$, which corresponds to 0.061 and 0.092 moles of $\mathrm{C}_{6} \mathrm{~F}_{5}$ groups per mole aluminum respectively. These data show that at a o.10 [M]/[Al] loading, the reaction of with sMAO with $\mathrm{B}\left(\mathrm{C}_{6} \mathrm{~F}_{5}\right)_{3}$ proceeds to a lesser extent (with respect to modifier group transfer) than the reaction of sMAO with $\mathrm{C}_{6} \mathrm{~F}_{5} \mathrm{OH}$, which is consistent with solution ${ }^{19} \mathrm{~F}$ NMR spectroscopy data under similar conditions.

The spatial distribution of aluminium and fluorine on the surface of the activating supports was investigated by Scanning Electron Microscopy (SEM) with Energy Dispersive X-Ray (EDX) spectroscopy. Elemental mapping (Figure $3 \mathrm{a}$ ) reveals a homogeneous distribution of aluminium and fluorine on the sMMAO particles, and line scans (Figure $3 \mathrm{~b}$ ) show the intensities of $\mathrm{Al} \mathrm{K \alpha}$ and $\mathrm{F} \mathrm{K \alpha}$ follow the particle topology. The EDX analyses are consistent with a higher fluorine content for $\operatorname{sMMAO}\left(0.20 / \mathrm{C}_{6} \mathrm{~F}_{5} \mathrm{OH}\right)$ with respect to $\operatorname{sMMAO}\left(0.20 / \mathrm{B}\left(\mathrm{C}_{6} \mathrm{~F}_{5}\right)_{3}\right.$ ) (Figures $\mathrm{S}_{26} 6-\mathrm{S}_{27}$ in the Supporting Information).

The specific surface area of the sMMAO samples was determined by analysis of the $\mathrm{N}_{2}$ gas physisorption isotherms using Brunauer-Emmett-Teller (BET) theory. All samples show a Type II isotherm (Figures $\mathrm{S}_{2} 8-\mathrm{S}_{40}$ in the Supporting Information), ${ }^{71}$ which is typically exhibited by inert gas physisorption on macroporous adsorbents. The BET data (Table 1) show a progressive decrease in specific surface area with increasing $\mathrm{B}\left(\mathrm{C}_{6} \mathrm{~F}_{5}\right)_{3}$ and $\mathrm{C}_{6} \mathrm{~F}_{5} \mathrm{OH}$ modifier loading, suggesting that the sterically demanding modifier groups are decorating the aluminoxane surface and blocking the porosity.

Table 1. Characterization data for sMMAO active supports with different $\mathrm{B}\left(\mathrm{C}_{6} \mathrm{~F}_{5}\right)_{3}$ and $\mathrm{C}_{6} \mathrm{~F}_{5} \mathrm{OH}$ modifier loadings.

\begin{tabular}{|c|c|c|c|c|c|c|}
\hline $\begin{array}{l}\text { Modifi- } \\
\text { er }(M)\end{array}$ & $\begin{array}{l}\text { Loading } \\
\left(\mathrm{mol}_{\mathrm{M}} / \mathrm{mol}_{\mathrm{A}}\right. \\
\left.{ }_{1}\right)\end{array}$ & $\begin{array}{l}\text { Yiel } \\
\text { d } \\
(\%)\end{array}$ & $\begin{array}{l}\text { Free } \\
\mathrm{AlMe}_{x} \\
\left(\mathrm{~mol}_{0} \%\right. \\
)\end{array}$ & $\begin{array}{l}\text { BET } \\
\left(\mathrm{m}^{2} \mathrm{~g}^{-1}\right)\end{array}$ & $\begin{array}{l}\mathrm{Al} \\
\mathrm{wt} \%\end{array}$ & $\begin{array}{l}\mathrm{F} \\
\mathrm{wt} \\
\%\end{array}$ \\
\hline Control & 0.00 & 98 & 18.3 & 580.9 & 38.5 & - \\
\hline \multirow[t]{4}{*}{$\mathrm{B}\left(\mathrm{C}_{6} \mathrm{~F}_{5}\right)_{3}$} & 0.01 & 91 & 14.9 & 558.9 & 38.1 & 2.36 \\
\hline & 0.05 & 97 & 8.5 & 494.1 & 36.4 & 5.82 \\
\hline & 0.10 & 91 & 7.1 & 460.6 & 32.5 & $\begin{array}{l}6.9 \\
4\end{array}$ \\
\hline & 0.20 & 73 & 6.2 & 430.9 & $25 \cdot 3$ & $7 \cdot 39$ \\
\hline $\mathrm{C}_{6} \mathrm{~F}_{5} \mathrm{OH}$ & 0.01 & 89 & 15.6 & 578.0 & 37.5 & 1.21 \\
\hline
\end{tabular}




$\begin{array}{llllll}0.05 & 99 & 10.9 & 554.2 & 36.8 & 5.43 \\ 0.10 & 91 & 5.3 & 531.9 & 34.4 & 11.2 \\ 0.20 & 95 & 1.6 & 440.3 & 25.4 & 18.4 \\ 0.40 & 84 & <0.1 & 406.8 & 18.0 & 26 . \\ & & & & & 4\end{array}$

\section{Slurry-phase ethylene polymerization studies}

The zirconocene pre-catalyst rac-ethylenebis(1-indenyl) zirconium dichloride, (EBI) $\mathrm{ZrCl}_{2}$, was immobilized on the surface of the sMMAO samples, by addition of toluene to

(a)
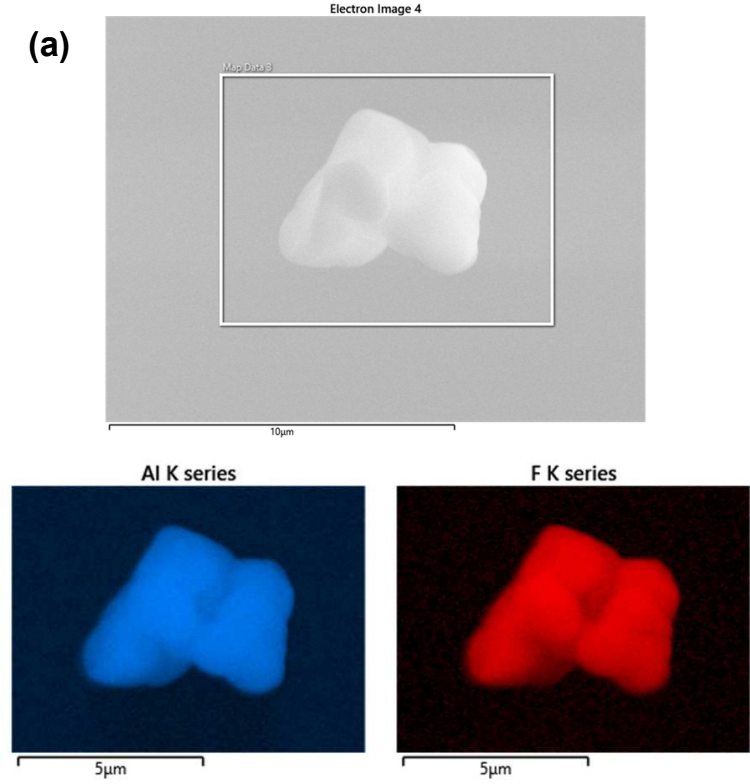

a mixture of solid support and complex ([Al]:[Zr] = 200:1), followed by heating at $60^{\circ} \mathrm{C}$ for $1 \mathrm{~h}$. After workup, bright orange powders were isolated in good yield $(>80 \%)$. The ethylene polymerization activity of these catalysts was tested to investigate the effect of $\mathrm{B}\left(\mathrm{C}_{6} \mathrm{~F}_{5}\right)_{3}$ and $\mathrm{C}_{6} \mathrm{~F}_{5} \mathrm{OH}$ modifiers on slurry polymerization with increasing $[\mathrm{M}] /[\mathrm{Al}]$ loading. A graphical summary of the data is shown in Figure 4, and the data are collated in Table 2.
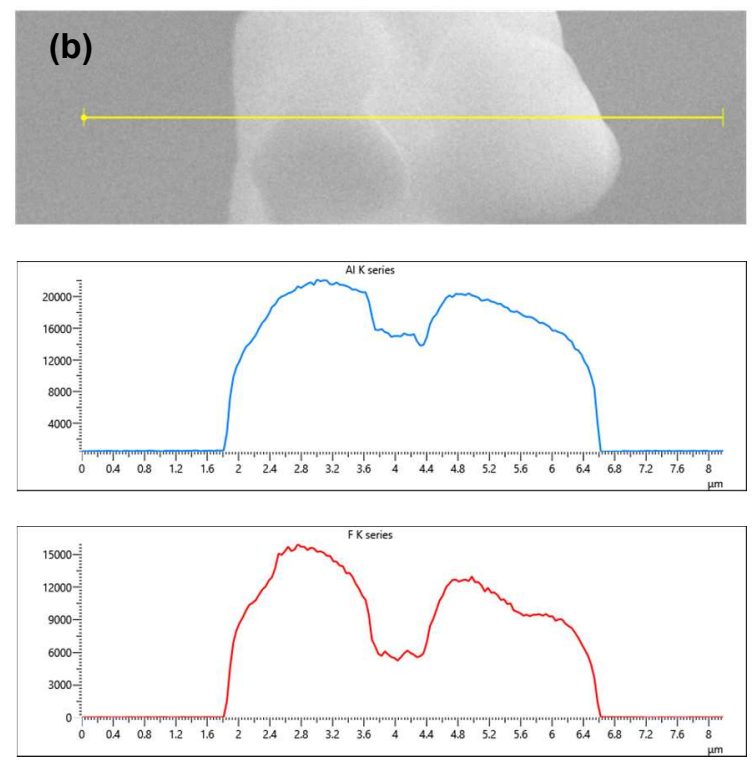

Figure 3. SEM-EDX analysis of sMMAO $\left(0.20 / \mathrm{C}_{6} \mathrm{~F}_{5} \mathrm{OH}\right)$ particles showing (a) elemental mapping and (b) line scans for aluminum (blue) and fluorine (red) K series.

Table 2. Ethylene polymerization and GPC data for $(\mathrm{EBI}) \mathrm{ZrCl}_{2}$ on sMMAO supports with various modifier loadings.

\begin{tabular}{lllll}
\hline $\begin{array}{l}\text { Modifi- } \\
\text { er }(\mathrm{M})\end{array}$ & $\begin{array}{l}\text { Loading } \\
\left(\mathrm{mol}_{\mathrm{M}} / \mathrm{mol}_{\mathrm{Al}}\right.\end{array}$ & $\begin{array}{l}\text { Activity } / 10^{4} \\
\left(\mathrm{~kg}_{\mathrm{PE}} \mathrm{mol}_{\mathrm{Zr}}{ }^{-}\right.\end{array}$ & $\begin{array}{l}M_{\mathrm{w}} \\
(\mathrm{kg} / \mathrm{mol}\end{array}$ & $\begin{array}{l}\text { PDI } \\
\left(M_{\mathrm{w}} / M_{\mathrm{n}}\right.\end{array}$ \\
\hline Control & 0.00 & 1.19 & 107.7 & 4.2 \\
\hline $\mathrm{B}\left(\mathrm{C}_{6} \mathrm{~F}_{5}\right)_{3}$ & 0.01 & 1.31 & 127.2 & 4.3 \\
& 0.05 & 1.36 & 101.6 & 4.0 \\
& 0.10 & 1.73 & 93.9 & 3.7 \\
& 0.20 & 1.98 & 79.2 & 3.9 \\
$\mathrm{C}_{6} \mathrm{~F}_{5} \mathrm{OH}$ & 0.01 & 1.29 & 156.4 & 4.7 \\
& 0.05 & 1.50 & 132.9 & 3.7 \\
& 0.10 & 1.54 & 122.3 & 4.1 \\
& 0.20 & 2.04 & 153.8 & 4.7 \\
& 0.40 & 1.54 & 203.3 & 4.9 \\
\hline
\end{tabular}

Polymerization conditions: sMMAO-(EBI) $\mathrm{ZrCl}_{2}, 10 \mathrm{mg}$ catalyst, 2 bar $\mathrm{C}_{2} \mathrm{H}_{4}, 70^{\circ} \mathrm{C}, 30 \mathrm{~min},[\mathrm{TIBA}]_{\mathrm{o}} /[\mathrm{Zr}]_{\mathrm{o}}=1000$, hexane $(50 \mathrm{~mL})$. All polymerization experiments were conducted at least twice to ensure the reproducibility of the corresponding outcome and mean activity values are quoted correct to 3 significant figures.

Both $\mathrm{B}\left(\mathrm{C}_{6} \mathrm{~F}_{5}\right)_{3}$ and $\mathrm{C}_{6} \mathrm{~F}_{5} \mathrm{OH}$ modified supports show a significant increase in polymerization activity with respect to the control sMAO, under identical pre-catalyst loading and polymerization conditions. Furthermore, there is a clear trend of increasing activity with $[\mathrm{M}] /[\mathrm{Al}]$ loading for both modifers. The maximum activity values occur at a $[\mathrm{M}] /[\mathrm{Al}]$ of 0.20 for $\mathrm{B}\left(\mathrm{C}_{6} \mathrm{~F}_{5}\right)_{3}\left(1.98 \times 10^{4}\right.$ $\left.\mathrm{kg}_{\mathrm{PE}} \mathrm{mol}_{\mathrm{Zr}}^{-1} \mathrm{~h}^{-1}\right)$ and $\mathrm{C}_{6} \mathrm{~F}_{5} \mathrm{OH}\left(2.04 \times 10^{4} \mathrm{~kg}_{\mathrm{PE}} \mathrm{mol}_{\mathrm{Zr}}^{-1} \mathrm{~h}^{-1}\right)$, which represent an increase of $66 \%$ and $71 \%$ respectively in comparison with the control sMAO $\left(1.19 \times 10^{4}\right.$ $\left.\mathrm{kg}_{\mathrm{PE}} \mathrm{mol}_{\mathrm{Zr}}{ }^{-1} \mathrm{~h}^{-1}\right)$.

Solid (EBI) $\mathrm{ZrCl}_{2}$-sMMAO catalysts were tested on a $2 \mathrm{~L}$ scale polymerization reactor, at an ethylene pressure of 8 bar. The ethylene consumption profiles for the modified supports (Figure 5) show an increase from 1 to $3 \mathrm{~min}$, consistent with exothermic catalyst initiation. ${ }^{72}$ The consumption profiles plateau out after $c a .7 \mathrm{~min}$, reaching a constant flow that is higher for $\operatorname{sMMAO}\left(0.10 / \mathrm{B}\left(\mathrm{C}_{6} \mathrm{~F}_{5}\right)_{3}\right)$ and sMMAO $\left(0.40 / \mathrm{C}_{6} \mathrm{~F}_{5} \mathrm{OH}\right)$ with respect to sMAO. After 30 min the $\mathrm{B}\left(\mathrm{C}_{6} \mathrm{~F}_{5}\right)_{3}$ modified catalyst shows a decrease in ethylene uptake, indicating that the active sites are less persistent. Overall, catalysts based on the modified sup- 
ports are active over a timescale of 1 hour and show higher final productivity values versus the control catalyst (see Table S19 in the Supporting Information for full polymerization data).

Rationalization of these observed activity tends is not immediately apparent, given the various differences in surface area, structure and composition for the modified supports, coupled with the poorly-defined nature of the immobilized zirconocene species involved in the polymerization. ${ }^{37,73-75}$ One plausible explanation for the observed trend is the decreased free $\mathrm{AlMe}_{x}$ content in the modified supports (Table 1). A similar trend has been reported in a number of homogenous polymerization catalyst systems, ${ }^{25,76,77}$ in which TMA-depleted MAOs were found to be more effective activators than MAO.

Another possibility is that the surface-bound $\mathrm{C}_{6} \mathrm{~F}_{5}$ and $\mathrm{C}_{6} \mathrm{~F}_{5} \mathrm{O}$ groups on the support lead to an increase in separation between the charged species formed after zirconocene activation, which in turn enhances the performance of the catalytically active species. Computational studies by Zurek and Ziegler of $\mathrm{MAO}$-activated $\mathrm{Cp}_{2} \mathrm{ZrMe}_{2}{ }^{-}$ catalyzed olefin polymerization (using a cage structure to model MAO) have correlated a larger ion-pair separation in the proposed active species with a lower barrier to ethylene insertion. ${ }^{78,79}$

The GPC data for the polyethylene produced by

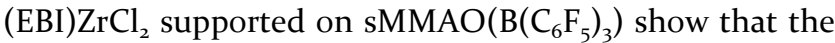
polyethylene molecular weights decrease with increasing modifier loading, ranging from 127.2 to $79.2 \mathrm{~kg} / \mathrm{mol}$, and polydispersities that are reasonably constant between 3.7 $<M_{\mathrm{w}} / M_{\mathrm{n}}<4.3$, compared with 4.2 for the control sMAO supported catalyst. The observed decrease in $M_{\mathrm{w}}$ is commensurate with a small enhancement of chain transfer to aluminum, ${ }^{80,81}$ which could be promoted by an increased concentration of Lewis acid sites in the $\mathrm{B}\left(\mathrm{C}_{6} \mathrm{~F}_{5}\right)_{3}$ modified catalyst systems. The polymers produced from sMMAO $\left(\mathrm{C}_{6} \mathrm{~F}_{5} \mathrm{OH}\right)-(\mathrm{EBI}) \mathrm{ZrCl}_{2}$ catalysts show generally higher molecular weights and polydispersities compared with those from sMAO and $\left.\operatorname{sMMAO}\left(\mathrm{B}_{(} \mathrm{C}_{6} \mathrm{~F}_{5}\right)_{3}\right)$ supported catalysts. This can be explained by a corresponding decrease in chain transfer to free $\mathrm{AlMe}_{x}{ }^{82}$ which has been depleted in the $\mathrm{C}_{6} \mathrm{~F}_{5} \mathrm{OH}$ modified catalyst systems. (a)

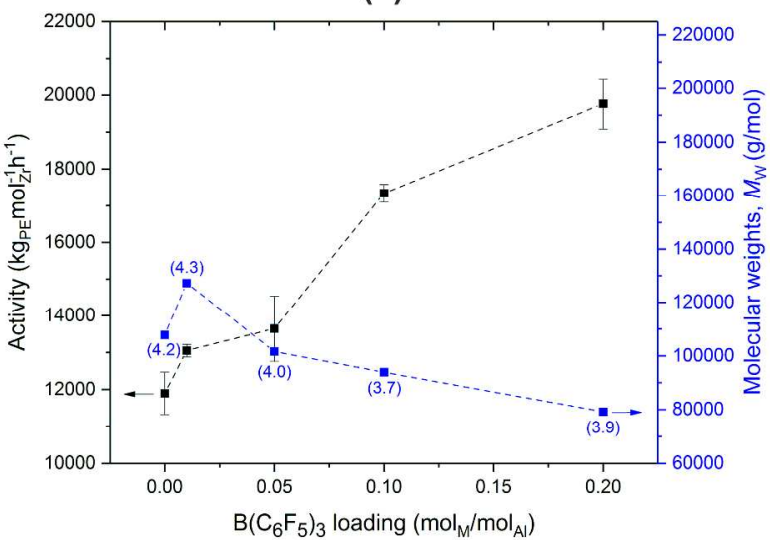

(b)

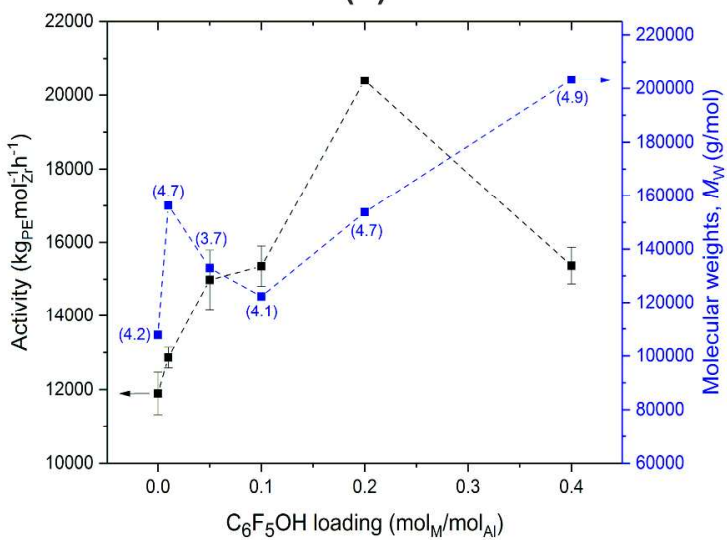

Figure 4. Ethylene polymerization activities for (EBI) $\mathrm{ZrCl}_{2}$ supported on sMMAO with variable loadings; $(\mathrm{a}) \mathrm{B}\left(\mathrm{C}_{6} \mathrm{~F}_{5}\right)_{3}$ and $(\mathrm{b})$ $\mathrm{C}_{6} \mathrm{~F}_{5} \mathrm{OH}$. Molecular weights $\left(M_{\mathrm{w}}\right)$, and polydispersities $\left(M_{\mathrm{w}} / M_{\mathrm{n}}\right)$. Activity $\left(\mathrm{kg}_{\mathrm{PE}} \mathrm{mol}_{\mathrm{Zr}^{-1}} \mathrm{~h}^{-1}\right)$ in black; molecular weights, $M_{\mathrm{w}}$ $(\mathrm{g} / \mathrm{mol})$, in blue; and polydispersities, $M_{\mathrm{w}} / M_{\mathrm{n}}$, in parentheses.

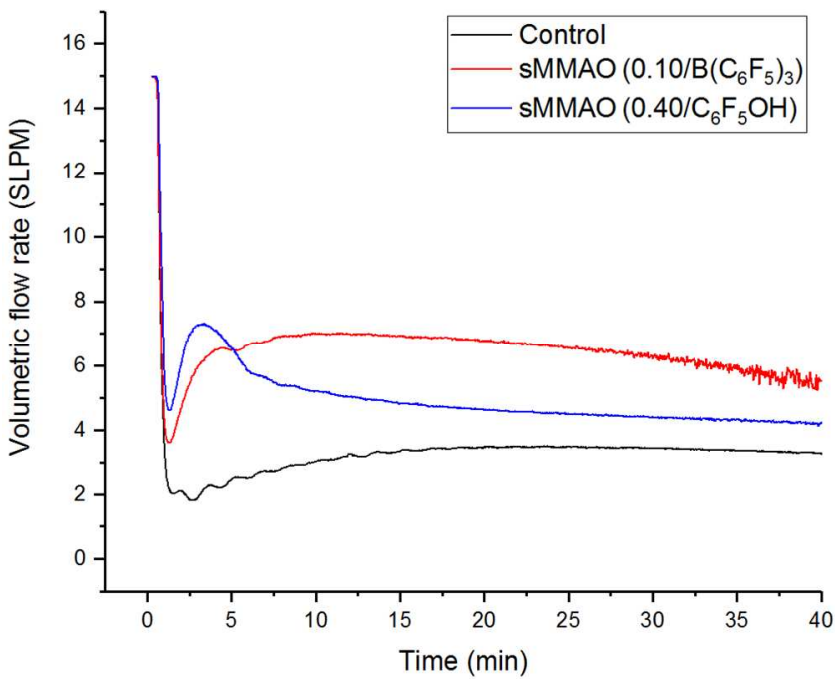

Figure 5. Ethylene flow in standard litre per minute (SLPM) during polymerization for (EBI) $\mathrm{ZrCl}_{2}-\mathrm{sMMAO}$ catalysts. Polymerization conditions: $25 \mathrm{mg}$ catalyst, 8 bar $\mathrm{C}_{2} \mathrm{H}_{4}, 8 \mathrm{o}{ }^{\circ} \mathrm{C}, \mathrm{AlEt}_{3}=2.5 \mathrm{~mL}$, hexane $(1000 \mathrm{~mL})$.

SEM images of the sMMAO samples reveal that the particle size and morphology is not significantly affected by $\mathrm{B}\left(\mathrm{C}_{6} \mathrm{~F}_{5}\right)_{3}$ modification with respect to the control (Figures $6 a-b)$. Furthermore, SEM images of polyethylene samples obtained from (EBI) $\mathrm{ZrCl}_{2}$ immobilized on sMMAO $\left(\mathrm{B}_{2}\left(\mathrm{C}_{6} \mathrm{~F}_{5}\right)_{3}\right)$ (Figure $\mathrm{S}_{49}-\mathrm{S}_{50}$ in the Supporting Information) show a popcorn-like morphology, confirming that the support acts as a template for the growing polymer chain. ${ }^{83}$ However, modification of the support with $\mathrm{C}_{6} \mathrm{~F}_{5} \mathrm{OH}$ results in disruption of this popcorn morphology, showing more jagged microstructure for the sMMAO (Figure 6c) and consequentially in the PE produced with 
(EBI) $\mathrm{ZrCl}_{2}$ (Figures $\mathrm{S}_{51}-\mathrm{S}_{52}$ in the Supporting Information).
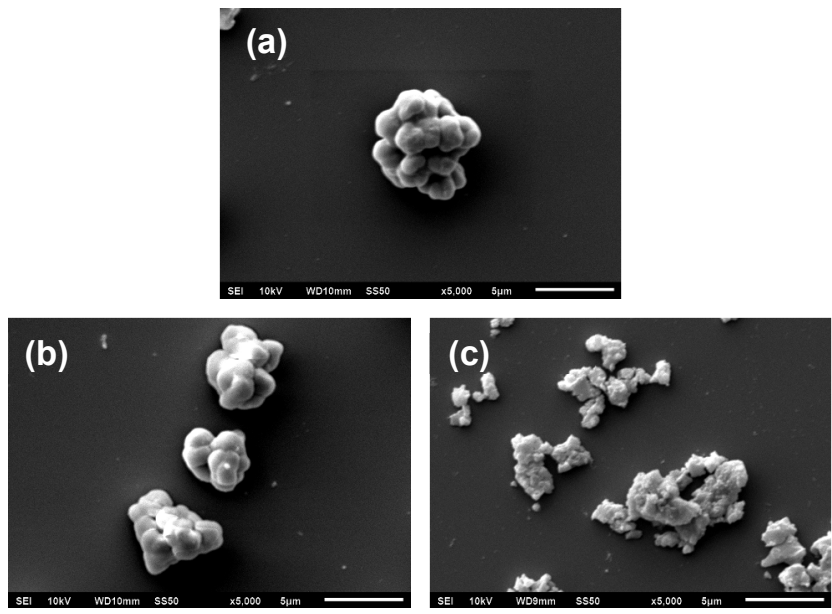

Figure 6. SEM images $(\times 5000$ magnification $)$ of catalyst supports; (a) sMAO(control); (b) $\operatorname{sMMAO}\left(0.10 / \mathrm{B}\left(\mathrm{C}_{6} \mathrm{~F}_{5}\right)_{3}\right)$; (c) sMMAO(o.10/ $\left.\mathrm{C}_{6} \mathrm{~F}_{5} \mathrm{OH}\right)$.

We postulate that methane gas released in the reaction of $\mathrm{C}_{6} \mathrm{~F}_{5} \mathrm{OH}$ with free $\mathrm{AlMe}_{x}$ has a "volcano-like" effect in the pores of the sMAO, which leads to the more angular morphology in the support at higher $\mathrm{C}_{6} \mathrm{~F}_{5} \mathrm{OH}$ modifier loadings. It is well-accepted that the particle fragmentation process is an extremely important step in determining the final morphology of a growing catalyst/polymer particle, and it can have a strong influence on the observed kinetics during the polymerization reaction. ${ }^{84}$

Polymer particle size is not significantly affected by $\mathrm{C}_{6} \mathrm{~F}_{5} \mathrm{OH}$ and $\mathrm{B}\left(\mathrm{C}_{6} \mathrm{~F}_{5}\right)_{3}$ sMMAO supports with respect to the unmodified sMAO.

At a $[\mathrm{M}] /[\mathrm{Al}]$ loading of 0.40 the $\mathrm{C}_{6} \mathrm{~F}_{5} \mathrm{OH}$ modifier has a retarding effect on the polymerization performance of the supported $(\mathrm{EBI}) \mathrm{ZrCl}_{2}$. This catalyst system displays an average activity of $1.54 \times 10^{4} \mathrm{~kg}_{\mathrm{PE}} \mathrm{mol}_{\mathrm{Zr}}{ }^{-1} \mathrm{~h}^{-1}$ and produces polyethylene with a significantly higher molecular weight $(203.3 \mathrm{~kg} / \mathrm{mol})$ and broader polydispersity $\left(M_{\mathrm{w}} / M_{\mathrm{n}}=4.9\right)$. SEM images of $\operatorname{sMMAO}\left(0.40 / \mathrm{C}_{6} \mathrm{~F}_{5} \mathrm{OH}\right)$ catalyst supports show a more angular morphology and a larger range of particle sizes (Figure $\mathrm{S}_{44}$ in the Supporting Information). Furthermore, the PE particles produced show a "cauliflower-like" structure (Figure $\mathrm{S}_{52}$ in the Supporting Information), which Kosek and co-workers have correlated with a non-uniform distribution of catalyst activity. ${ }^{85,86}$

The ${ }^{1} \mathrm{H}$ NMR spectrum of $\operatorname{sMMAO}\left(0.40 / \mathrm{C}_{6} \mathrm{~F}_{5} \mathrm{OH}\right)$ in THF- $d_{8}$ shows less than $0.1 \%$ free $\mathrm{AlMe}_{x}$, and we postulate that the exhaustive reaction of $\mathrm{AlMe}_{x}$ with $\mathrm{C}_{6} \mathrm{~F}_{5} \mathrm{OH}$ leads to the rough morphology observed. The ${ }^{19} \mathrm{~F}$ NMR spectrum of sMMAO $\left(0.40 / \mathrm{C}_{6} \mathrm{~F}_{5} \mathrm{OH}\right)$ shows three sets of $o-/ p$ $/ \mathrm{m}-\mathrm{F}$ resonances (Figure $\mathrm{S} 8$ in the Supporting Information), consistent with multiple $\mathrm{C}_{6} \mathrm{~F}_{5} \mathrm{O}$ environments and a non-uniform surface composition.

\section{CONCLUSIONS}

Solid polymethylaluminoxane samples have been modified with $\mathrm{B}\left(\mathrm{C}_{6} \mathrm{~F}_{5}\right)_{3}$ and $\mathrm{C}_{6} \mathrm{~F}_{5} \mathrm{OH}$ at four different loadings.
These solids have been extensively characterized using solution and solid-state NMR spectroscopy, DRIFTS, SEM-EDX, $\mathrm{N}_{2}$ physisorption and ICP-MS analysis. The characterization data are consistent with a reduced amount of 'free' $\mathrm{AlMe}_{x}$ and incorporation of $\mathrm{C}_{6} \mathrm{~F}_{5}$ and $\mathrm{C}_{6} \mathrm{~F}_{5} \mathrm{O}$ groups onto the sMAO surface structure. Ethylene polymerization using $(\mathrm{EBI}) \mathrm{ZrCl}_{2}$ immobilized on the modified polymethylaluminoxanes show that as the modifier loading $([\mathrm{M}] /[\mathrm{Al}])$ is increased from o to 0.20 , the polymerization activity increases for $\mathrm{B}\left(\mathrm{C}_{6} \mathrm{~F}_{5}\right)_{3}$ and $\mathrm{C}_{6} \mathrm{~F}_{5} \mathrm{OH}$ by $66 \%$ and $71 \%$ respectively, under identical zirconium loading and polymerization conditions.

Excellent control of the polymer molecular weight and morphology is maintained in the case of the $\mathrm{B}\left(\mathrm{C}_{6} \mathrm{~F}_{5}\right)_{3}$ modified polymethylaluminoxane. We postulate that the incorporation of aluminum-bound $\mathrm{C}_{6} \mathrm{~F}_{5}$ groups leads to an increased concentration of Lewis acid sites in this active support. In contrast, $\mathrm{C}_{6} \mathrm{~F}_{5} \mathrm{OH}$ modified polymethylaluminoxane results in particles with a more angular morphology, and the polyethylene produced shows more irregular particle shapes compared with the unmodified control catalyst. We postulate that the reaction of $\mathrm{C}_{6} \mathrm{~F}_{5} \mathrm{OH}$ and 'free' $\mathrm{AlMe}_{x}$ within the pores of sMAO causes a distortion in the support morphology and leads to a non-uniform distribution of active sites.

Investigations are underway to probe the surface interaction of the immobilized zirconocene with the sMAO, and fully rationalize how modification of the support with electron-withdrawing arylfluorine groups leads to the observed enhancement in catalytic activity.

\section{ASSOCIATED CONTENT}

\section{Supporting Information}

The Supporting Information is available free of charge on the ACS Publications website.

Experimental details (general procedures, syntheses and characterization data and ethylene polymerization), additional characterizing data (solution and solid state NMR spectroscopy, DRIFT spectroscopy, SEM-EDX analysis, BET surface area, SEM imaging of supports), polymerization studies (activity data for synthesized SMMAO supports, SEM and GPC for polyethylene samples) (PDF)

\section{AUTHOR INFORMATION}

\section{Corresponding Author}

*E-mail: dermot.ohare@chem.ox.ac.uk.

\section{Notes}

Any additional relevant notes should be placed here.

\section{ACKNOWLEDGMENT}

A.F.R.K. and J.-C.B. thank SCG Chemicals Co., Ltd for funding. We are grateful to Mr P. Angpanitcharoen and Miss J. Lamb (University of Oxford) for SEM imaging and Mrs J. A. Holter (David Cockayne Centre for Electron Microscopy, Oxford Materials) for SEM-EDX analysis. We thank Dr N. Nealmongkolrattana and $\mathrm{Mr} \mathrm{T}$. Parawan (SCG Chemicals) for assistance with modification reactions and polymerization testing respectively. A.F.R.K. also thanks Wadham College Oxford for a RJP Williams Junior Research Fellowship. 


\section{REFERENCES} (1), 19-43. 309-367. 5,066,631 1991. 1998. 1999. 1554-1557. 8751-8754. 1434.
(1) Zijlstra, H. S.; Harder, S. Eur. J. Inorg. Chem. 2o14, 2015

(2) Sinn, H. Macromol. Symp. 1995, 97 (1), $27-52$.

(3) Reddy, S. S.; Sivaram, S. Prog. Polym. Sci. 1995, 20 (2),

(4) Busico, V. Dalton Trans. 2oo9, 41 (41), 8794-8802.

(5) Luo, L.; Sangokoya, S. A.; Wu, X.; Diefenbach, S. P.; Kneale, B. US Pat. oo62492 A1 2009.

(6) Ghiotto, F.; Pateraki, C.; Tanskanen, J.; Severn, J. R.; Luehmann, N.; Kusmin, A.; Stellbrink, J.; Linnolahti, M.; Bochmann, M. Organometallics 2013, 32 (11), 3354-3362.

(7) Henderson, M. A.; Trefz, T. K.; Collins, S.; Wang, M. Y.; McIndoe, J. S. Organometallics 2013, 32 (7), 2079-2083.

(8) Trefz, T. K.; Henderson, M. A.; Wang, M. Y.; Collins, S.; McIndoe, J. S. Organometallics 2013, 32 (11), 3149-3152.

(9) Trefz, T. K.; Henderson, M. A.; Linnolahti, M.; Collins, S.; McIndoe, J. S. Chem.-Eur. J. 2014, 21 (7), 2980-2991.

(10) Zijlstra, H. S.; Linnolahti, M.; Collins, S.; McIndoe, J. S. Organometallics 2017, 36 (9), 1803-1809.

(11) Hirvi, J. T.; Bochmann, M.; Severn, J. R.; Linnolahti, M. ChemPhysChem 2014, 15 (13), 2732-2742.

(12) Linnolahti, M.; Collins, S. ChemPhysChem 2017, DOI:10.1002-cphc.201700827.

(13) Fischer, D.; Jüngling, S.; Mülhaupt, R. Macromol. Symp. 1993, 66 (1), 191-202.

(14) Sangokoya, S. A.; Howie, M. S.; Trombo, T. A. US Pat.

(15) Kristen, M. O.; Fischer, D. PCT Int. Appl. 98/40418

(16) Lee, C. H.; Lee, S. J.; Park, J. W.; Kim, K. H.; Lee, B. Y.; Oh, J. S. J. Mol. Catal. A: Chem. 1998, 132 (2), 231-239.

(17) Marks, T. J.; Yang, X.; Mirviss, S. B. US Pat. 5,939,346

(18) Busico, V.; Cipullo, R.; Cutillo, F.; Friederichs, N.; Ronca, S.; Wang, B. J. Am. Chem. Soc. 2003, 125 (41), 12402-12403.

(19) Kissin, Y. V. Macromolecules 2003, 36, 7413-7421.

(20) Kissin, Y. V. Macromol. Rapid Commun. 2oo4, 25 (17),

(21) Ye, J.; Jiang, B.; Qin, Y.; Zhang, W.; Chen, Y.; Wang, J.; Yang, Y. RSC Adv. 2015, 5 (116), 95981-95993.

(22) Ronca, S.; Romano, D.; Forte, G.; Andablo-Reyes, E.; Rastogi, S. Adv. Polym. Technol. 2012, 31 (3), 193-204.

(23) Mark, S.; Kurek, A.; Mülhaupt, R.; Xu, R.; Klatt, G.; Köppel, H.; Enders, M. Angew. Chem. Int. Ed. Engl. 2o10, 49 (46),

(24) Rouholahnejad, F.; Mathis, D.; Chen, P. Organometallics 2010, 29 (2), 294-302.

(25) Tynys, A.; Eilertsen, J. L.; Rytter, E. Macromol. Chem. Phys. 2006, 207 (3), 295-303.

(26) Ciardelli, F.; Altomare, A.; Michelotti, M. Catal. Today 1998, 41 (1-3), 149-157.

(27) Fink, G.; Steinmetz, B.; Zechlin, J.; Przybyla, C.; Tesche, B. Chem. Rev. 2000, 100 (4), 1377-1390.

(28) Heurtefeu, B.; Bouilhac, C.; Cloutet, É.; Taton, D.; Deffieux, A.; Cramail, H. Prog. Polym. Sci. 2o11, 36 (1), 89-126.

(29) Severn, J. R.; Chadwick, J. C.; Duchateau, R.; Friederichs, N. Chem. Rev. 2005, 105 (11), 4073-4147.

(30) Soga, K.; Kim, H. J.; Shiono, T. Macromol. Chem. Phys. 1994, 195 (10), 3347-3360.

(31) Chen, E. Y.; Marks, T. J. Chem. Rev. 200o, 100 (4), 1391-

(32) Tian, J.; Soo-Ko, Y.; Metcalfe, R.; Feng, Y.; Collins, S. Macromolecules 2001, 34 (10), 3120-3122.

(33) McKittrick, M. W.; Jones, C. W. J. Am. Chem. Soc. 2004, 126 (10), 3052-3053.
(34) Hicks, J. C.; Mullis, B. A.; Jones, C. W. J. Am. Chem Soc. 2007, 129 (27), 8426-8427.

(35) McDaniel, M. P.; Jensen, M. D.; Jayaratne, K.; Collins, K. S.; Benham, E. A.; McDaniel, N. D.; Das, P. K.; Martin, J. L.; Yang, Q.; Thorn, M. G.; Masino, A. P. In Tailor-Made Polymers; Severn, J. R., Chadwick, J. C., Eds.; Wiley-VCH Verlag GmbH \& Co. KGaA, 2008; pp 171-210.

(36) Prades, F.; Broyer, J.-P.; Belaid, I.; Boyron, O.; Miserque, O.; Spitz, R.; Boisson, C. ACS Catal. 2013, 3 (10), 22882293.

(37) Buffet, J.-C.; Wanna, N.; Arnold, T. A. Q.; Gibson, E. K.; Wells, P. P.; Wang, Q.; Tantirungrotechai, J.; O'Hare, D. Chem. Mater. 2015, 27 (5), 1495-1501.

(38) Buffet, J.-C.; Byles, C. F. H.; Felton, R.; Chen, C.; O'Hare, D. Chem. Commun. 2016, 52, 4076-4079.

(39) Kumamoto, S.; Katayama, H.; Imai, A. Jpn. Laid-Open Appl. 09249707A 1997.

(40) Sauter, D. W.; Popoff, N.; Bashir, M. A.; Szeto, K. C.; Gauvin, R. M.; Delevoye, L.; Taoufik, M.; Boisson, C. Chem. Commun. 2016, 52 (26), 4776-4779.

(41) Hlatky, G. G. Chem. Rev. 2ooo, 100 (4), 1347-1376.

(42) Bartke, M.; Oksman, M.; Mustonen, M.; Denifl, P. Macromol. Mater. Eng. 2005, 290 (4), 250-255.

(43) Kilpatrick, A. F. R.; Buffet, J.-C.; Nørby, P.; Rees, N. H.; Funnell, N. P.; Sripothongnak, S.; O'Hare, D. Chem. Mater. 2016, 28 (20), 7444-7450.

(44) Arnold, T. A. Q.; Turner, Z. R.; Buffet, J.-C.; O'Hare, D. J. Organomet. Chem. 2016, 822, 85-90.

(45) Buffet, J.-C.; Arnold, T. A. Q.; Turner, Z. R. Angpanitcharoen, P.; O'Hare, D. RSC Adv. 2015, 5 (106), 8745687464 .

(46) Linnolahti, M.; Severn, J. R.; Pakkanen, T. A. Angew. Chem. Int. Ed. Engl. 2008, 47 (48), 9279-9283.

(47) Falls, Z.; Tymińska, N.; Zurek, E. Macromolecules 2014, 47 (24), 8556-8569.

(48) Kaji, E.; Yoshioka, E. US Pat. 8,404,88o B2 2013

(49) McKenna, T. F. L. Macromol. Symp. 2007, 260 (1), 65-

73.

(50) Kittilsen, P.; Svendsen, H. F.; McKenna, T. F. AIChE J. 2003, 49 (6), 1495-1507.

(51) McKenna, T.; Mattioli, V. Macromol. Symp. 20o1, 173 (1), 149-162.

(52) Kittilsen, P.; McKenna, T. F.; Svendsen, H.; Jakobsen, H. A.; Fredriksen, S. B. Chem. Eng. Sci. 2001, 56 (13), 4015-4028.

(53) Klosin, J.; Roof, G. R.; Chen, E. Y.-X.; Abboud, K. A. Organometallics 2000, 19 (23), 4684-4686.

(54) Chen, C.; Kehr, G.; Fröhlich, R.; Erker, G. J. Am. Chem. Soc. 2010, 132 (39), 13594-13595.

(55) Amo, V.; Andrés, R.; de Jesús, E.; de la Mata, F. J.; Flores, J. C.; Gómez, R.; Gómez-Sal, M. P.; Turner, J. F. C. Organometallics 2005, 24 (10), 2331-2338.

(56) Mathis, D.; Couzijn, E. P. A.; Chen, P. Organometallics 2011, 30 (14), 3834-3843.

(57) Rocchigiani, L.; Busico, V.; Pastore, A.; Macchioni, A. Dalton Trans. 2013, 42 (25), 9104-9111.

(58) Wanglee, Y.-J.; Hu, J.; White, R. E.; Lee, M.-Y.; Stewart, S. M.; Perrotin, P.; Scott, S. L. J. Am. Chem. Soc. 2011, 134 (1), 355366.

(59) Hahn, E. L. Phys. Rev. 1950, 80, 580-594.

(6o) Panchenko, V. N.; Semikolenova, N. V.; Danilova, I. G.; Paukshtis, E. A.; Zakharov, V. A. J. Mol. Catal. A: Chem. 1999, 142 (1), 27-37.

(61) Eilertsen, J. L.; Rytter, E.; Ystenes, M. Vib. Spectrosc. 2000, 24 (2), 257-264.

(62) Ystenes, M.; Eilertsen, J. L.; Liu, J.; Ott, M.; Rytter, E.; Støvneng, J. A. J. Polym. Sci. A Polym. Chem. 200o, 38 (17), 31063127. 
(63) Bergquist, C.; Bridgewater, B. M.; Harlan, C. J.; Norton, J. R.; Friesner, R. A.; Parkin, G. J. Am. Chem. Soc. 2ooo, 122 (43), 10581-10590.

(64) Massey, A. G.; Park, A. J. J. Organomet. Chem. 1964, 2 (3), 245-250.

(65) Millot, N.; Santini, C. C.; Fenet, B.; Basset, J.-M. Eur. J. Inorg. Chem. 2002, 2002 (12), 3328-3335.

(66) Millot, N.; Santini, C. C.; Lefebvre, F.; Basset, J.-M. C. $R$. Chim. 2004, 7 (8-9), 725-736.

(67) Busca, G. Catal. Today 1998, 41 (1-3), 191-206.

(68) Bagshaw, S. A.; Cooney, R. P. Chem. Mater. 1993, 5, 1101-1109.

(69) Barzetti, T.; Selli, E.; Moscotti, D.; Forni, L. J. Chem. Soc. Faraday Trans. 1996, 92 (8), 1401-1407.

(70) Zaki, M. I.; Hasan, M. A.; Al-Sagheer, F. A.; Pasupulety,

L. Colloids Surf., A 2001, 190 (3), 261-274.

(71) Thommes, M.; Kaneko, K.; Neimark, A. V.; Olivier, J. P.; Rodriguez-Reinoso, F.; Rouquerol, J.; Sing, K. S. W. Pure Appl. Chem. 2015, 87 (9-10), 1051-1069.

(72) Pater, J. T. M.; Weickert, G.; van Swaaij, W. P. M. AIChE J. 2003, 49 (2), 450-464.

(73) Silveira, F.; Alves, M. C. M.; Stedile, F. C.; Pergher, S. B.; dos Santos, J. H. Z. J. Mol. Catal. A: Chem. 2010, 315 (2), 213220.

(74) Jezequel, M.; Dufaud, V.; Ruiz-Garcia, M. J.; CarrilloHermosilla, F.; Neugebauer, U.; Niccolai, G. P.; Lefebvre, F.;
Bayard, F.; Corker, J.; Fiddy, S.; Evans, J.; Broyer, J.-P.; Malinge, J.; Basset, J.-M. J. Am. Chem. Soc. 2001, 123 (15), 3520-3540.

(75) O'Brien, S.; Tudor, J.; Maschmeyer, T.; O'Hare, D. Chem. Commun. 1997, 1905-1906.

(76) Ghiotto, F.; Pateraki, C.; Severn, J. R.; Friederichs, N.; Bochmann, M. Dalton Trans. 2013, 42 (25), 9040-9048.

(77) Pédeutour, J.-N.; Cramail, H.; Deffieux, A. J. Mol. Catal. A: Chem. 2001, 174 (1), 81-87.

(78) Zurek, E.; Ziegler, T. Prog. Polym. Sci. 2004, 29 (2), 107148.

(79) Zurek, E.; Ziegler, T. Organometallics 2002, 21 (1), 8392.

(8o) Quintanilla, E.; di Lena, F.; Chen, P. Chem. Commun. 2006, o (41), 4309-4311.

(81) Petros, R. A.; Norton, J. R. Organometallics 2004, 23 (22), 5105-5107.

(82) Busico, V.; Cipullo, R.; Cutillo, F.; Friederichs, N.; Ronca, S.; Wang, B. J. Am. Chem. Soc. 2003, 125 (41), 12402-12403.

(83) Junges, F.; de Souza, R. F.; dos Santos, J. H. Z.; Casagrande, O. L. Macromol. Mater. Eng. 2005, 290 (1), 72-77.

(84) McKenna, T. F.; Soares, J. B. P. Chem. Eng. Sci. 2001, 56 (13), 3931-3949.

(85) Grof, Z.; Kosek, J.; Marek, M. Ind. Eng. Chem. Res. 2005, 44 (8), 2389-2404.

(86) Grof, Z.; Kosek, J.; Marek, M. AIChE J. 2005, 51 (7), 2048-2067. 
Solid MAO

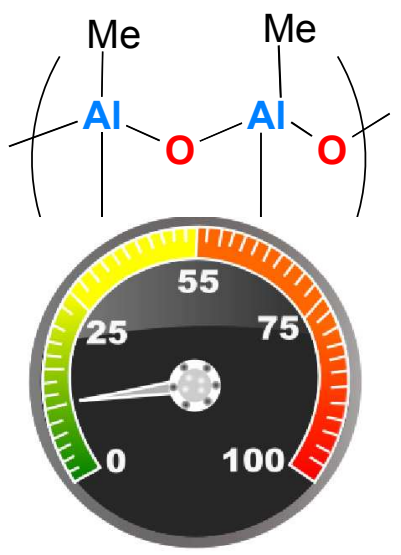

Modified Solid MAO
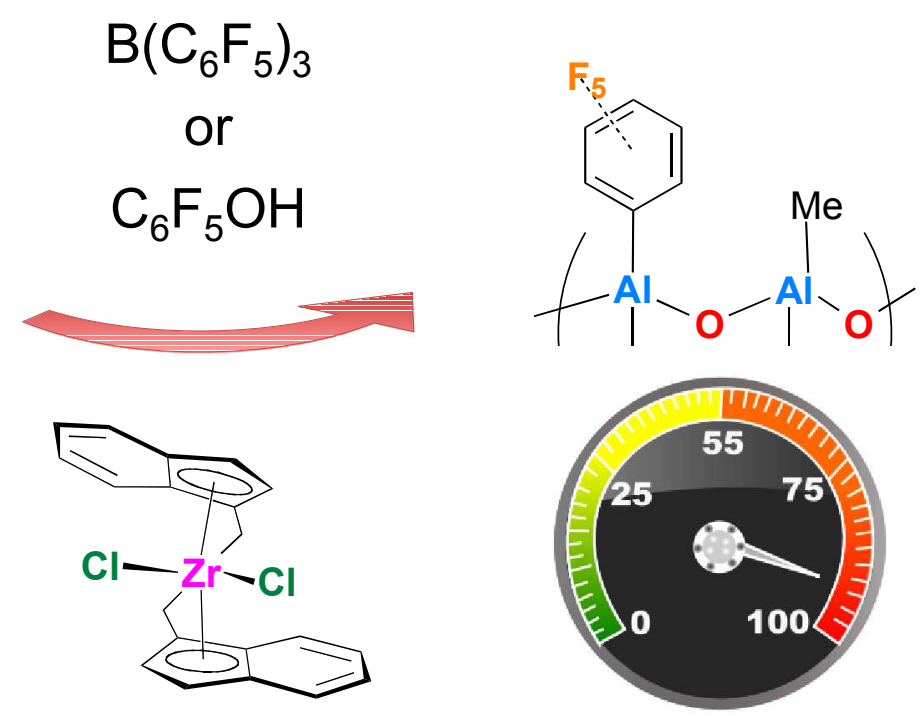

Enhanced Activity Support for Ethylene Polymerization 
Solid MAO

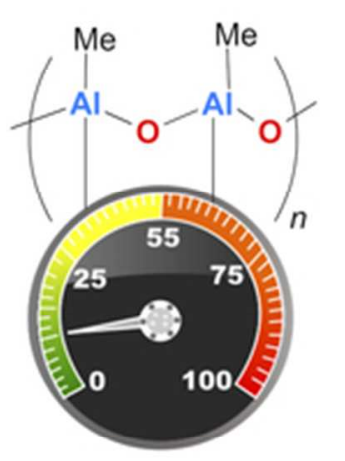

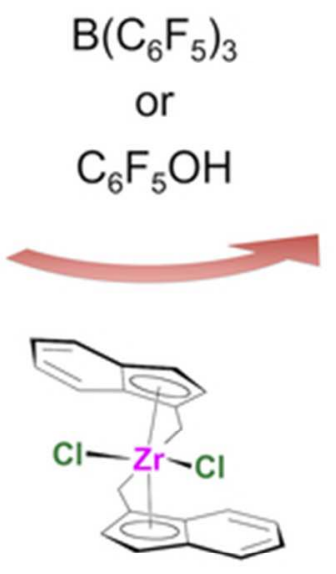

\section{Modified Solid MAO}

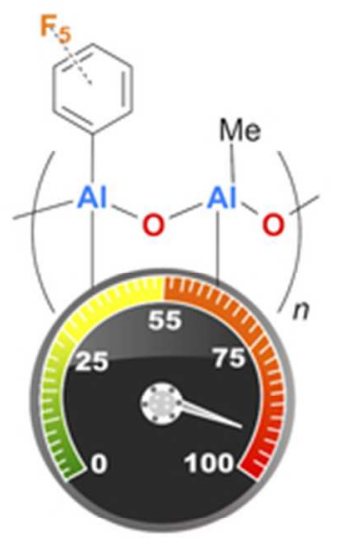

\section{Enhanced Activity Support for Ethylene Polymerization}

Tris(pentafluorophenyl)borane or pentafluorophenol modified solid polymethylaluminoxane produces highly active metallocene supports for ethylene polymerization.

$47 \times 26 \mathrm{~mm}(300 \times 300$ DPI $)$ 